\title{
Design and construction of a prototype of an unmanned aerial vehicle equipped with artificial vision for the search of people
}

\author{
Andrés Espinal-Rojas ${ }^{1}$ / andresfelipeespinal@gmail.com \\ Andrés Arango-Espinal ${ }^{1}$ / andres_ae90@yahoo.com \\ Luis Ramos ${ }^{1}$ / djmosquerap@udistrital.edu.co \\ Jorge Humberto Erazo Aux ${ }^{1,2}$ / langelramosl@gmail.com \\ ${ }^{(1)}$ Institución Universitaria Antonio José Camacho, Cali-Colombia \\ (2)Universidad del Valle, Cali-Colombia
}

ABSTRACT This paper describes the development and implementation of a six-pointed Unmanned Aerial Vehicle [UAV] prototype, designed for finding lost people in hard to access areas, using Arduino MultiWii platform. A platform capable of performing a stable flight to identify people through an on-board camera and an image processing algorithm was developed. Although the use of UAV represents a low cost and quick response -in terms of displacement- solution, capable to prevent or reduce the number of deaths of lost people in away places, also represents a technological challenge, since the recognition of objects from an aerial view is difficult, due to the distance of the UAV to the objective, the UAV's position and its constant movement. The solution proposed implements an aerial device that performs the image capture, wireless transmission and image processing while it is in a controlled and stable flight.

KEYWORDS Drone; UAV; image processing; flight control; MultiWii; facial recognition.

Diseño y construcción de un prototipo de vehículo aéreo no tripulado equipado con visión artificial para la búsqueda de personas

RESUMEN Se desarrolló un prototipo de Vehículo Aéreo no Tripulado [UAV] de seis puntas, diseñado para buscar personas extraviadas en zonas de difícil acceso, con Arduino MultiWii, capaz de realizar un vuelo estable para efectuar, en conjunto con un algoritmo de procesamiento de imágenes, la correcta búsqueda de personas a través de una cámara a bordo. Si bien usar un UAV puede reducir el costo, aumentar la velocidad de respuesta en las tareas de rescate y reducir el número de personas perdidas en lugares lejanos e incomunicados muertas, también representa un reto tecnológico: el reconocimiento de objetos desde el aire, debido a la distancia entre el UAV y su objetivo, la posición del UAV y su constante movimiento. La solución propuesta plantea la implementación de un dispositivo aéreo que captura imágenes, para su envío de manera inalámbrica y su procesamiento, mientras el UAV se encuentra en un vuelo controlado y estable.

PALABRAS CLAVE Drón; vehículo aéreo no tripulado; procesamiento de imágenes; control de vuelo; MultiWii; reconocimiento facial.
Desenho e construção de um protótipo de veículo aéreo não-tripulado equipado com visão artificial para a busca de pessoas

RESUMO Se apresenta o desenvolvimento e implementação de um protótipo de Veículo Aéreo Não-tripulado [UAV] de seis pontas, desenhado para a busca de pessoas desaparecidas em áreas de dificil acesso, implementado usando Arduino MultiWii, capaz de realizar um voo estável para efetuar, juntamente com um algoritmo de processamento de imagem, a busca certa de pessoas através de uma câmera a bordo. Enquanto o uso de UAVs tem o potencial para reduzir o custo e aumentar a velocidade de resposta nas tarefas de resgate, e pode reduzir o número de mortes de pessoas perdidas em lugares distantes e isolados, também representa um desafio tecnológico: o reconhecimento de objetos desde o ar, devido à distância entre o UAV e o seu objetivo, a posição do UAV e seu movimento constante, conformam uma barreira tecnológica para superar. A solução proposta apresenta a implementação de um dispositivo aéreo que capta imagens, para o seu envoi sem uso de fios e o seu processamento, enquanto o UAV está em um voo controlado e estável.

PALAVRAS-CHAVE Drone; veículo aéreo não tripulado; processamento de imagens; controle de voo; MultiWii; reconhecimento facial. 


\section{Introduction}

The drones arose as military technological tools oriented to reconnaissance and attack missions in warlike operations. The term was born in the 90 s and replaces the Remotely Piloted Vehicles [RPV] one, term used from World War I and applied to Unmanned Aerial Vehicles [UAV] including robotics (Newcome, 2004; DoD, 2017). The UAV term is the common denomination nowadays and they are used as intelligence platform equipped with modern radars, image acquisition systems, and communications.

The private companies pushed both the mass production of the drones and the rise and growing of commercial applications involving them. Within their applications, some to outline are the ones related with the image processing - for its potential for data analysis in the agricultural sector-, the civil constructions, the optical analysis, and the search of missing people in open places. The universities have also supported the research in this area, as the work presented by Torres, Gómez \& Jimenez (2015) and Taborda \& Velázquez (2013) show.

Although there are many types of applications even some merely recreative--, one of the most noted usages is the search of missing people in open places - e.g., desert zones or in the ocean - and hard-to-reach or hostile places. This task usually depends on the organization of people in rescue teams that register the compromised area without aerial support (excepting helicopters), entailing low and slow response times (Guerrero \& Coronel, 2013).

The reduced size of the drones and their low-cost facilitate their acquisition and guarantee a high availability. Their usage helps reducing the response time and increase the effectiveness in search operations through the gathering of images from an aerial perspective.

In this document, we propose the design and construction of an UAV prototype that works as a platform to search people using image processing obtained in the flight. With the intention of achieving this, certain parameters should be considered as the design of a structure with the correct morphology of the drone allowing the image gathering in flight, the design of a communication system that allows the sending of such images to a fixed base in the ground, and the design and implementation of a control and artificial vision systems for the correct flight and identification of people in the ground.

\section{Introducción}

Los drones se originan como herramientas tecnológicas militares destinadas a misiones de reconocimiento y ataque en operaciones bélicas. El término nace en los años 90 y sustituye al de Vehículos Tripulados Remotamente [VTR], el cual había sido utilizado desde la primera guerra mundial, y se aplica a los vehículos aéreos no tripulados que incluyen robótica (Newcome, 2004; DoD, 2017). Estos últimos dispositivos se conocen como UAV [Unmanned Aerial Vehicle] y se han utilizado como plataforma de inteligencia, equipados con sofisticados radares, sistemas de adquisición de imágenes y comunicaciones.

Las empresas privadas impulsaron la producción en masa de los primeros drones, así como la aparición y el crecimiento de aplicaciones comerciales que los involucran. Dentro de las aplicaciones se destacan algunas relacionadas con el procesamiento de imágenes, por su potencial para análisis de datos en el sector agrícola, las obras civiles y el análisis óptico, y la búsqueda de personas desaparecidas en lugares abiertos, las empresas privadas han impulsado la producción en masa de los primeros drones, así como la aparición y crecimiento de aplicaciones comerciales que los involucran. Las universidades, como se puede apreciar en los trabajos de Torres, Gómez y Jimenez (2015), y Taborda y Velázquez (2013), también han aportado a ello.

Aunque hay aplicaciones de todo tipo, incluso meramente recreativas, uno de los usos más destacados corresponde a la citada búsqueda de personas desaparecidas en lugares abiertos -zonas desérticas o mar abierto-, de difícil acceso o clasificados como hostiles: Esta tarea hasta hace poco dependía de la organización de personas en grupos de rescate competentes para registrar el área comprometida, sin ayudas de éste tipo (exceptuando helicópteros convencionales), con respuestas lentas y poco eficientes (Guerrero \& Coronel, 2013).

El tamaño reducido de estos vehículos y su bajo costo, facilitan su adquisición y garantizan una alta disponibilidad. Su uso ayuda a reducir el tiempo de respuesta e incrementa la efectividad en operaciones de búsqueda, por medio de la adquisición de imágenes desde una vista aérea.

En este documento se plantea el diseño y la construcción de un prototipo de vehículo aéreo no tripulado que sirva de plataforma para la búsqueda de personas utilizando procesamiento de imágenes obtenidas en vuelo; para cumplir con este fin, se deben tener en cuenta ciertos parámetros, como son: el diseño de una estructura con la correcta morfología del drón, que permita la toma de imágenes en vuelo; el diseño de un sistema de comunicación, que permita enviar dichas imágenes a una base en tierra; y por último, el diseño e implementación de un sistema de control y de visión artificial, para el correcto vuelo y la identificación de la existencia de personas en tierra.

En lo que resta de este documento: se describe la plataforma de experimentación, se presenta una explicación funcional del sistema software implementado, se relacionan algunas de las pruebas desarrolladas y, finalmente, se presentan las conclusiones y algunas perspectivas de trabajos futuros. 


\section{PLATAFORMA DE EXPERIMENTACIÓN}

En la Figura 1 se observan los principales componentes del hardware del drón, el sistema debe iniciar con la orden del usuario a través de un transmisor que envié una señal de forma inalámbrica para que sea recibida por el receptor que se encuentra montado en el dispositivo. Esta señal recibida le indica qué movimiento realizar, según lo decida el usuario.

La señal, luego de ser recibida, es procesada por la unidad de control, la que decidirá cómo realizar estos movimientos gracias al algoritmo implementado en ella y a los sensores conectados al drón que le indican si éste se encuentra en el ángulo correcto, con la orientación correcta. Luego de que la unidad de control central decide cómo realizar este movimiento, es decir, qué potencia darle a cada motor, enviará la señal PWM [Pulse-Width Modulation]) correspondiente a cada variador que funciona como interfaz de potencia entre el hardware de control y los motores para finalmente mover los motores a la potencia indicada, generando así los movimientos deseados por el piloto.

El hardware del sistema, como se aprecia en la Figura 1, está dividido en seis bloques interconectados: motores y variadores; batería; transmisor y receptor RG [Radio Control]; unidad de control y sensores; transmisor/receptor de video y cámara; y plataforma de tres ejes de movimiento con seis puntas motoras.

\section{Motores y variadores}

Se encargan de generar el empuje necesario para la elevación y control del UAV. La correcta selección de los motores se relaciona con la propulsión requerida por cada motor para sostener el vuelo, y está descrita en la ecuación 1. En esta relación, usada en el aeromodelismo, se asume el doble del peso real del vehículo como parámetro de seguridad:
In the subsequent parts of this document, we describe the experimentation platform, we present a functional explanation of the implemented software, we correlate some developed tests and we present the conclusions and future work this research entailed.

\section{EXPERIMENTATION PLATFORM}

In FiguRE 1, we present the main hardware components of the drone, the system must start with the order of the user through a transmitter that sends a wireless signal to be received by the module in the device. This signal indicates the movements to perform as per the user requires it.

The signal, after being received, is processed by the control unit; this unit will decide how to perform the requested movements thanks to the implemented algorithm within it and to the sensors connected to the drone. These sensors indicate if the UAV is in the correct angle and orientation. After the control unit decides how to perform the movement (i.e., the amount of power to supply to each engine), it sends the Pulse-Width Modulation [PWM] signal corresponding to each controller that works as a power interface between the control hardware and the engines to move them with the adequate power, generating the requested movements.

The hardware of the system - displayed in FIGURE 1 is partitioned in six interconnected blocks: engines and controllers, battery, Radio Control [RG] transmitter and receiver, control unit plus sensors, video transceiver/receiver plus camera, and the last block is the three-axis platform with six motor edges.

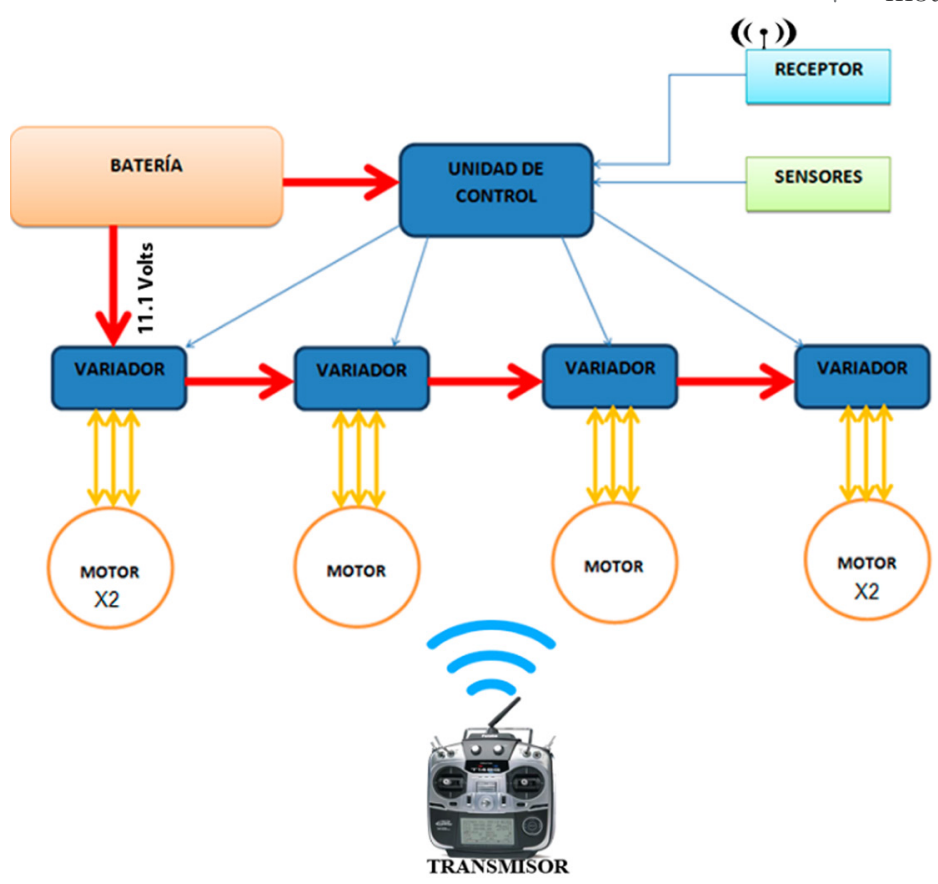

Figure 1. Block diagram of the hardware and system connections / Diagrama de bloques del hardware y conexiones del sistema

\section{Engines and controllers}

They are in charge of generating the necessary force for the elevation and control of the UAV. The correct selection of the engines is related with the required propulsion in each engine to maintain the flight and it is described in Equation 1. In that relation — used in the making of model airplanes-, the double of the real weight of the vehicle is assumed as a security parameter:

$$
\begin{gathered}
\text { Empuje por motor }=(\text { pesoTotal }) \times \frac{2}{\# \text { DeMotores }}(1) \\
\text { Empuje de motor }=\frac{1.600 \times .2}{6} \mathrm{~g}=533 \mathrm{~g}
\end{gathered}
$$

From the previous result, we selected the Multistar 350 brushless engine, with a maximum force of 510 grams, generating $920 \mathrm{KV}$ (rpm/volt) and capable to deliver a maximum of 10,212 rpm. It can be fed at maximum 12.6 volts and 20 amperes 
and its dimensions are 27 by $23 \mathrm{~mm}$, with an engine axis of $5 \mathrm{~mm}$ to insert the airscrew. The used controller (Afro 30 ) is optocoupled with the control signal and it receives the PWM signal delivered by the control unit at $1 \mathrm{kHz}$. It also has a 15 AWG male connector of $3.5 \mathrm{~mm}$ for coupling with the battery and a 16 AWG female connector of $3.5 \mathrm{~mm}$ for the engines. The controller weight is $26.5 \mathrm{~g}$ (including the cables) and its size is 50 by 25 by $11 \mathrm{~mm}$, which eases its incorporation in the arms of the structure.

\section{Battery}

It is a must-have to know if the battery supports the maximum current the six engines can demand when they are operating at full power (Equation 2).

\section{Corriente constante $=20 \mathrm{~A} \times 6=120 \mathrm{~A}$}

In order to know if the battery supports this current in a constant way, the value $(\mathrm{C})$ of discharge has to be analyzed from the datasheet provided by the manufacturer. For instance, if the datasheet specifies a value of discharge $(\mathrm{C})$ of $40 \mathrm{C}$ and the battery has a capacity of $3,700 \mathrm{mAh}$, that means a constant current of 148 amperes is acceptable by the battery.

\section{Corriente constante soportada $=40 \times 3.700 \mathrm{~mA}=148 \mathrm{~A}$}

Based on the previous statement, we selected a Zippy Compact branded battery, one of the commercially available brands with best $\mathrm{mAh} /$ weight balance. Its type is Li-Po with a capacity of $3,700 \mathrm{mAh}$ and it has 3 cells at $11.1 \mathrm{~V}$. It also presents a discharge at $40 \mathrm{C}$ constant (148 amperes in a constant way) per $50 \mathrm{C}$ burst, a weight of $317 \mathrm{~g}$ (including cables and connectors) and its dimensions are 148 by 44 by $25 \mathrm{~mm}$; finally, it has a JST-XH connector to monitor the charging level of each cell and other XT-60 connector used to supply the battery with energy.

\section{$R C$ transmitter and receiver}

This application requires, as minimal, four transmission channels that allow the execution of each flight movement: rotation in the vertical axis, rotation in the longitudinal axis, rotation of the transversal axis, and engine power. The use of simple communication protocols can generate the UAV to be adrift; for this reason, we used the Futaba FASST technology, along with the T8FG Super remote control (Futaba brand, also) at $2.4 \mathrm{GHz}$, which allows an ease programming and provides the necessary channels for the applications. Furthermore, it is compatible with the $\mathrm{RC}$ receiver (8-chan-

$$
\begin{gathered}
\text { Empuje por motor }=(\text { pesoTotal }) \times \frac{2}{\text { \#DeMotores }}(1) \\
\text { Empuje de motor }=\frac{1.600 \times .2}{6} \mathrm{~g}=533 \mathrm{~g}
\end{gathered}
$$

A partir del resultado anterior, se selecciona el motor Multistar 350 brushless, con un empuje máximo de 510 gramos, que genera $920 \mathrm{KV}$ (Rpm / voltio) y puede entregar un máximo de 10.212 RPM. Se puede alimentar máximo a 12,6 voltios y 20 amperios, y sus dimensiones son 27 x $23 \mathrm{~mm}$, con un eje de motor de $5 \mathrm{~mm}$ para acoplar la hélice. El variador utilizado (Afro 30) está opto acoplado con la señal de control, recibe la señal PWM entregada por la unidad de control a $1 \mathrm{kHz}$ y posee un conector tipo 15 AWG/macho de $3.5 \mathrm{~mm}$, para acople con la batería, y otro conector tipo $16 \mathrm{AWG} /$ hembra de $3.5 \mathrm{~mm}$, para los motores. Su peso es de $26.5 \mathrm{~g}$ (incluyendo los cables) y su tamaño es de $50 \times 25 \times 11 \mathrm{~mm}$, lo que facilita su incorporación en los brazos de la estructura.

\section{Batería}

Se debe conocer si la batería soporta la máxima corriente que consumen los seis motores cuando todos se encuentran a máxima potencia (ecuación 2):

\section{Corriente constante $=20$ A $\times 6=120 A$}

Para conocer si la batería soporta esta corriente de forma constante se debe analizar el valor $(\mathbf{C})$ de descarga en la hoja de especificaciones proporcionada por el fabricante. Por ejemplo, si la ficha técnica especifica un valor $(\mathrm{C})$ de descarga de $40 \mathrm{C}$ y es una batería de $3.700 \mathrm{mAh}$, ello indica que soporta de forma constante una corriente de 148 Amperios.

Corriente constante soportada $=40 \times 3.700 \mathrm{~mA}=148 \mathrm{~A}$

Con base en lo anterior, se selecciona una batería de la marca Zippy Compact, una de las marcas en el mercado que maneja el mejor balance $\mathrm{mAh} /$ peso; es de tipo LI-Po con una capacidad de $3.700 \mathrm{mAh}$ de 3 celdas a $11,1 \mathrm{~V}$, tiene una descarga de 40C constante (148 Amperios de forma constante) / 50C ráfaga, un peso de $317 \mathrm{~g}$ (incluyendo cables y conectores); sus dimensiones son: 148x44x25 mm, y tiene un conector tipo JST-XH para monitorear el nivel de carga de cada celda y otro conector tipo XT60 usado para suministrar la energía.

\section{Transmisor y receptor $R C$}

Esta aplicación requiere mínimo cuatro canales de transmisión que permitan realizar cada movimiento de vuelo: rotación sobre su eje vertical, rotación sobre su eje longitudinal, rotación del eje transversal y potencia de los motores. El uso de protocolos de comunicación sencillos puede generar que el vehículo quede a la deriva, razón por la cual se usa la tecnología FASST de Futaba, junto con el control 
remoto T8FG Super de Futaba a 2.4 Ghz (gigahercios), que permite una fácil programación y cuenta con los canales necesarios para la aplicación, guardando además compatibilidad con el receptor RC (R6208SB de ocho canales y tecnología FASST) (Futaba, 2017). El dispositivo receptor utiliza comunicación de datos en serie para enviar señales de control hacia los rotores, con opciones de alimentación entre 3,5 y 8,4 V, y un peso de 13,8 gramos.

\section{Unidad de control y sensores}

Para controlar el funcionamiento de los motores se usa el controlador MultiWii de referencia MPU-6050; esta plataforma posee un giróscopo y un compás, y además permite detectar el ángulo de inclinación para los ejes $\mathrm{X}$ y $\mathrm{Y}$. El sensor posee un rango $(\%$ seg) de \pm 2.000 con un rango $(\mathrm{G})$ de \pm 16 , resolución de 16 bits, comunicación I2C, alimentación entre 2.3 y $3.4 \mathrm{~V}$ y sensibilidad (LSB $/ \%$ sec) de 16.4. También se cuenta con un magnetómetro HMC5883L para ser usado como brújula, con rango gauss de \pm 8 con resolución de 5 miligauss, comunicación I2C, ADC 12 bits, alimentación entre 2,1 y 3,6 V.

Transmisor / receptor de video y cámara

Para la selección de la cámara se revisaron características como el peso, la resolución, el campo de visión [FOV], la resistencia a golpes, la estabilización y la frecuencia de adquisición de imágenes. Comparando las características anteriores sobre dos modelos comerciales (GoPro Hero y HeliStar Sony HLSCM001), se descartó la primera referencia por su elevado peso, pues los otros parámetros son muy semejantes en ambos dispositivos. Con relación a los transmisores, se encontraron algunas referencias comerciales como SkyZone TS5823, Immersion R y FastShark V3, los cuales presentan un bajo peso y son utilizadas para aeromodelismo; teniendo en cuenta que el dispositivo SkyZone tiene parámetros similares a sus semejantes en otras marcas, se decidió utilizar el TS5823 por su bajo precio.

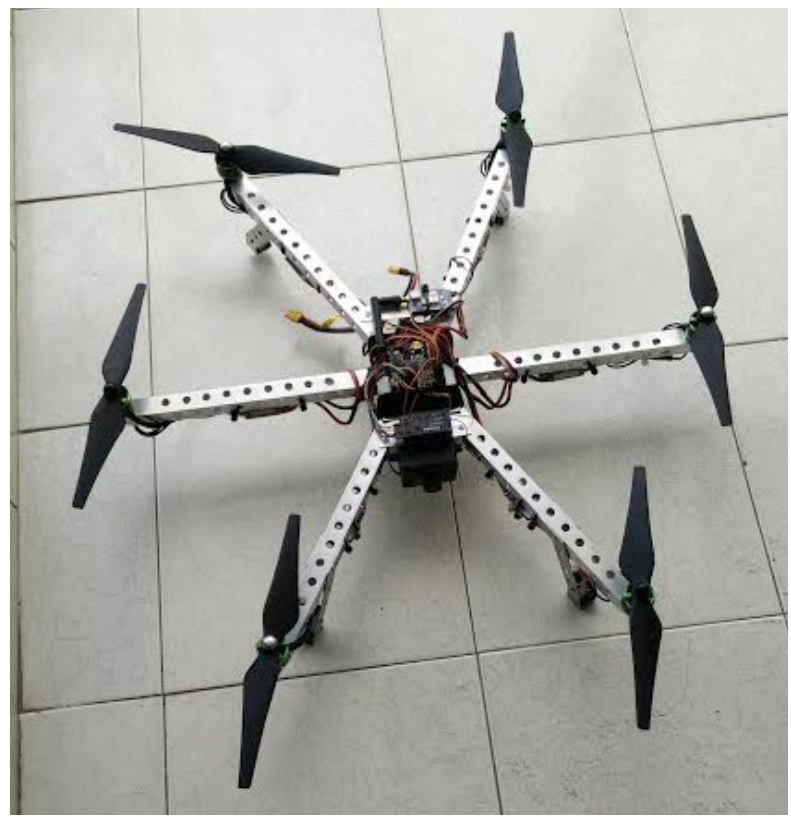

Figure 2. Implemented platform (three axes and six motor edges) / Plataforma implementada (tres ejes y seis puntas motoras) nel, FASST technology R6208SB) (Futaba, 2017). The receiver device uses serial data communication to send control signals to the rotors, with supply options of 3.5 and $8.4 \mathrm{~V}$ with a weight of $13.8 \mathrm{~g}$.

\section{Control unit and sensors}

With the aim of controlling the operation of the engines, we employed the MultiWii controller with reference MPU-6050. This platform has a gyroscope and a compass that allows the detection of the inclination angle for the $\mathrm{X}$ and $\mathrm{Y}$ axis. The sensor has a range $(\% / \mathrm{sec})$ of \pm 2,000 with a range $(\mathrm{G})$ of $\pm 16,16$ bits of resolution, I2C communication, supply power between 2.3 and 3.4 $\mathrm{V}$, and sensitivity (LSB/\% / sec) of 16.4. It also has a HMC5883L magnetometer to be used as a compass, with gauss range of $\pm 8,5$ milligauss of resolution, $\mathrm{I} 2 \mathrm{C}$ communication, 12 bits of $\mathrm{ADC}$, and supply power between 2.1 and $3.6 \mathrm{~V}$.

\section{Video transmitter / receiver and camera}

For the selection of the camera, we checked features as the weight, resolution, the field of vision [FOV], the shock resistance, the stabilization, and the image gathering frequency. Comparing the previous features in two commercially available models (GoPro Hero and HeliStar Sony HLS-CM001), we discarded the first reference due to its considerable weight, the remaining parameters are relatively similar in both devices. Regarding the transmitters, we found some commercial references as the SkyZone TS5823, Immersion R, and FastShark V3, which present a low weight and are used for making model airplanes. Considering that the SkyZone device has similar parameters to similar cameras of other brands, we decided to use the TS5823 for its low price.

\section{Three-axis of movement platform with six motor edges}

There are different multi-airscrew chassis versions (unibody, racing, and composed). Considering aspects as weight, physical space for the electronics, and robustness to support possible forced landings and the opposite forces of the engines, we decided to use a composed chassis that is generally made of aluminum, connecting each part with rivets. The chassis cannot be built with wood, since the vibrations would be transmitted to the sensors of the flight controller and it would not allow a correct operation.

With the aim of knowing the required thrust per engine, we proceeded to estimate the total weight of the drone in the six engines proposed in the design (see FiguRE 1). The weight of the hardware is approximately 881 


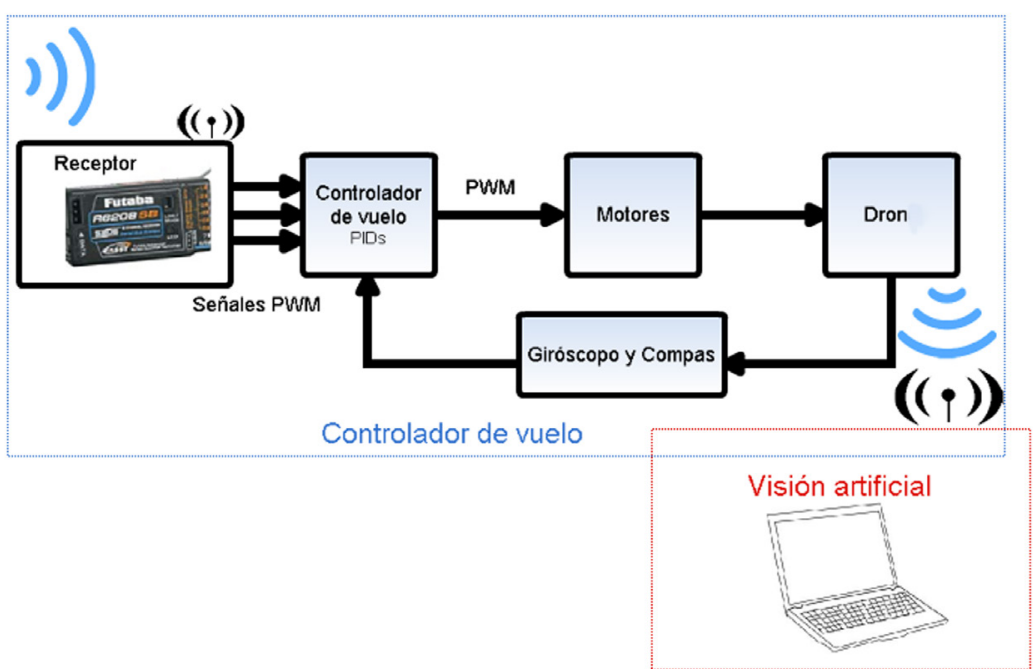

Figure 3. General operation of the system - Block diagram / Funcionamiento general del sistema - diagrama de bloques

Plataforma de tres ejes de movimiento con seis puntas motoras

Existen diferentes versiones de chasis de tipo multi-hélice (unibody, de carreras y compuesto). Teniendo en cuenta aspectos como peso, espacio físico para la integración de la electrónica y robustez para soportar posibles aterrizajes forzosos y las fuerzas opuestas de los motores, se decidió hacer uso de un chasis compuesto, que generalmente está fabricado en aluminio, conectando cada parte con remaches. El chasis no puede ser construido con madera, ya que sus vibraciones se transmiten a los sensores del controlador de vuelo y no permiten un correcto funcionamiento.

Para conocer el empuje necesario por motor se procede a estimar el peso total del drón sobre los seis motores propuestos en el diseño (ver Figura 1). El peso del hardware es de

grams as the total sum of its parts: battery with $317 \mathrm{~g}$, six engines for a total of $238.8 \mathrm{~g}$, receiver with $13.8 \mathrm{~g}$, control unit with 14g, six Electronic Speed Control [ESG] units with $159 \mathrm{~g}$, cables and connectors with $100 \mathrm{~g}$, transmitter with $25 \mathrm{~g}$, and camera with $13.5 \mathrm{~g}$. This total value, compared with the objective weight of all the device of $1,600 \mathrm{~g}$ gives us an autonomy of $719 \mathrm{~g}$ that can be employed for the construction of the chassis.

The required thrust per engine in accordance with the described relation is $(\mathrm{G}) 533$ grams/engine; for this reason, we chose the Multistar 350 engine — with 510 grams of thrust. Consequently, the drone will be able to provide a thrust almost as twice as its weight, which will stabilize out possible imbalances and disturbances caused by the wind. In Figure 2, the central design of the UAV is presented with the manner the electronic elements are placed plus the design of the six rotors with their corresponding landing bases. This latter allows the location of the camera in the frontal region.

\section{FUNCTIONAL DESCRIPTION}

At the software level, the developed system integrates two main blocks necessary for its operation (see FigurE 3). The first one, associated to the flight controller is in charge of supervising the tasks associated to the movement; this, to ensure the UAV responds in an adequate manner through the MultiWii board and using open source code. The second block is responsible for the acquisition, transmission, reception, and posterior processing of the image for the detection of people; the latest task is achieved using MATLAB and the Vision.CascadeObjectDetector function. aproximadamente 881 gramos, lo que resulta de la suma de sus partes: batería: 317 g; seis motores: 238.8 g; receptor: 13.8 g; unidad de control 14 g; seis ESC [Electronic Speed Control]: 159 g; cables/conectores: 100 g; transmisor: 25 g; y cámara 13.5 g. Este valor, restado al objetivo de $1600 \mathrm{~g}$ propuesto para todo el dispositivo, deja una autonomía de 719 gramos, que se puede emplear para la construcción del chasis.

El empuje por motor necesario de acuerdo con la relación descrita es de (G) 533 gramos/motor, por lo cual se escogen los motores Multistar 350 de 510 gramos de empuje; de esta forma, el drón será capaz de proporcionar un empuje de casi el doble de su peso, lo cual compensará desequilibrios y disturbios por causa del viento. En la Figura 2 se observa el diseño central del UAV, la forma en que se disponen los elementos electrónicos y el diseño de seis rotores con sus correspondientes bases de aterrizaje que permite la ubicación de la cámara en la región frontal.

\section{DESCRIPCIÓN FUNCIONAL DE LA APLI- CACIÓN}

A nivel software, el sistema desarrollado integra dos bloques principales necesarios para su funcionamiento (ver FIGURA 3): el primero, asociado al controlador de vuelo, se encarga de

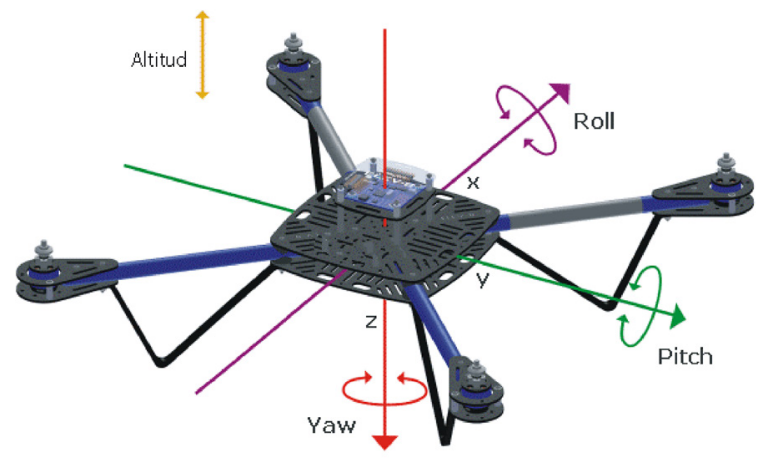

Figure 4. Drone movements (Issod, 2015) / Movimientos del drón (Issod, 2015) 


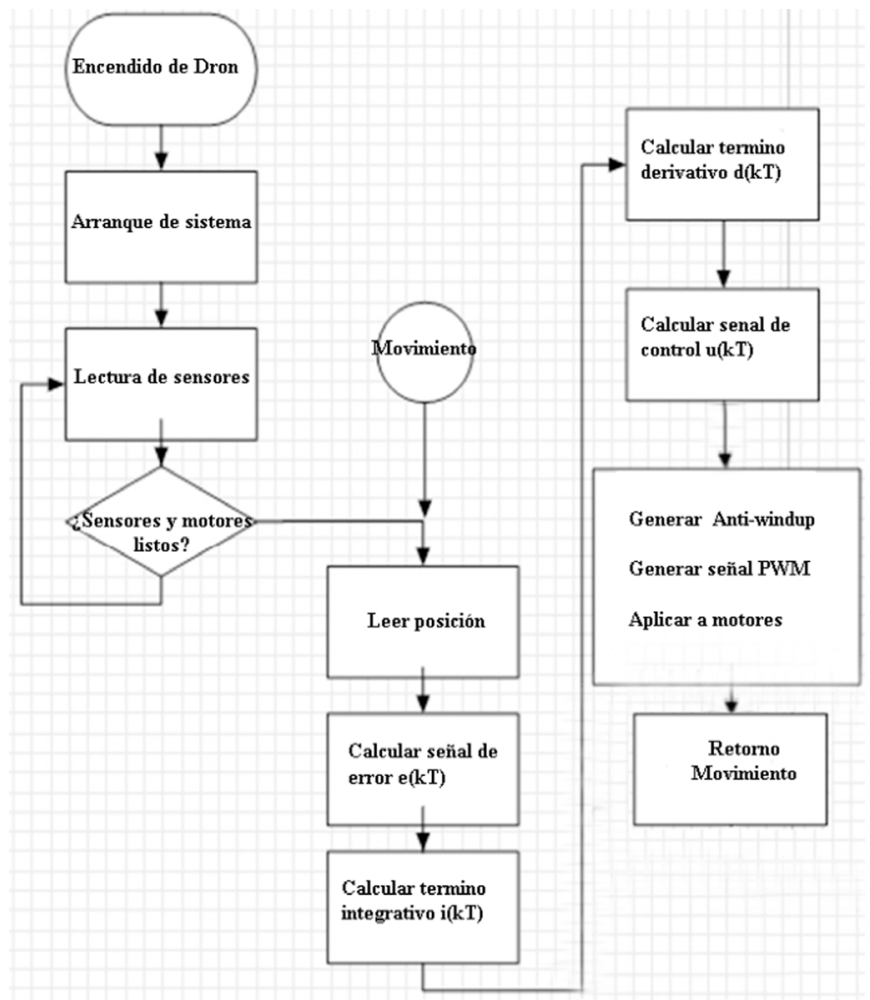

Figure 5. Flow diagram for the flight controller algorithm / Diagrama de flujo - algoritmo para el controlador de vuelo

supervisar las tareas asociadas a sus movimiento para que el UAV responda de manera adecuada a través de la placa MultiWii y haciendo uso de su software de código abierto; el segundo, encargado de la adquisición, transmisión/recepción de la imagen y su posterior procesamiento para la detección de personas, donde la última tarea se logra a través de Matlab y la función "Vision.CascadeObjectDetector".

\section{A. Implementación del controlador de web}

El controlador MultiWii tiene implementados tres controladores PID, que conducen los movimientos en términos de inclinación y giro, como se aprecia en la Figura 4.

Es necesario utilizar un bucle cerrado controlado para asegurar, tanto la estabilidad, como la maniobrabilidad. Esto se logra con un control PID para cada eje (X, Y y Z), disminuyendo la inestabilidad propia del diseño basado en rotores. El giróscopo se encarga de detectar qué tan rápido se presentan los movimientos involuntarios en vuelo y el ángulo formado entre la horizontal y la inclinación que se tiene en los ejes roll y pitch. La brújula permite detectar los movimientos de rotación.

Después que los sensores envían la información al controlador, ésta se compara con el set-point de ángulo dado por el operario a través del control remoto, y el controlador realiza el cálculo de la señal manipulada, aplicando los componentes proporcionales, integrales y derivativos.

En la Figura 5 se presenta el algoritmo del sistema de control de vuelo, donde primero se evalúa una condición de inicio, luego se lee la posición actual que entregan los

\section{A. Implementation of the flight controller}

The MultiWii controller has three PID controllers implemented, which drive the movements in terms of tilt and turn, as it is appreciated in Figure 4.

It is necessary to use a controlled closed loop to ensure both the stability and the maneuverability. This is achieved with a PID controller for each axis $\mathrm{X}, \mathrm{Y}$, and $\mathrm{Z})$, reducing the instability of the design based on rotors. The gyroscope is responsible of detecting how fast the involuntary movements are present in the flight and the change in the angle between the horizontal and the tilt in the roll and pitch axis (FIGURE 4). The compass allows to detect the rotation movements.

After the sensors send the information to the controller, it is compared with the set-point of the given angle by the operator through the remote control; then, the controller performs the calculation of the manipulated signal by applying the proportional, integral, and derivative connectors.

In Figure 5, we present the algorithm of the flight control system where, at the beginning, a start condition is assessed; then the current position is read from the sensors and the error is calculated, together with the integrative and derivative terms. Finally, with the proportional constant, the calculation of the control signal to be converted in the PWM signal for the engines is performed by considering some anti-windup, which will fix the inferior and superior limits of the generated values.

At the end, to determine the engines that the PID controls will change their power (see FigurE 6), it is necessary to know the movement type the operator performed through the remote control. If the movement is ahead or backwards,

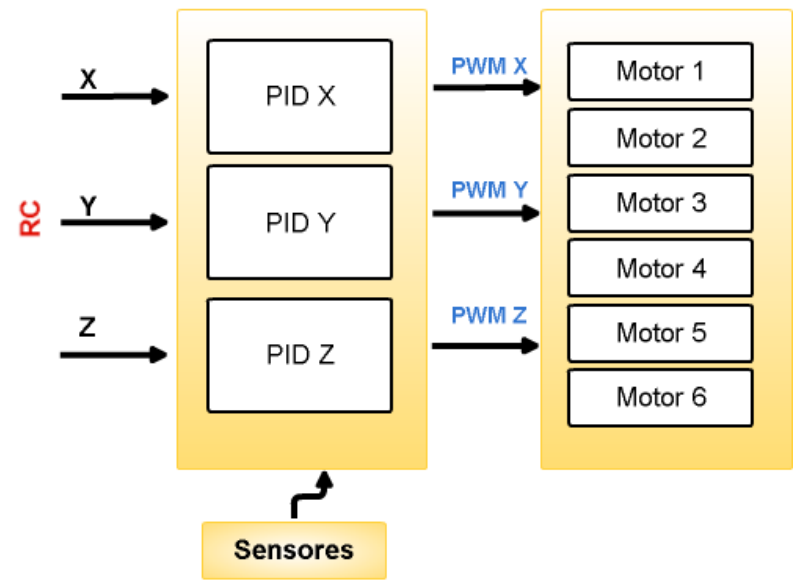

Figure 6. Scheme of the operation for each axis / Esquema funcionamiento para cada eje 

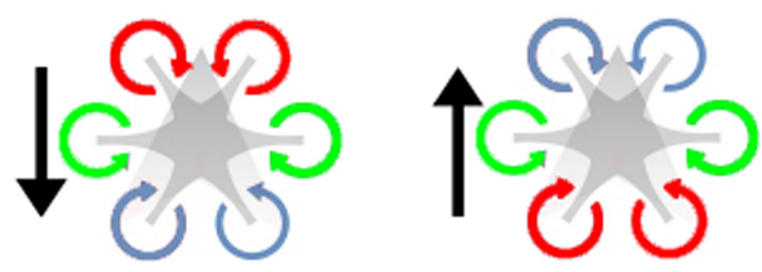

Figure 7. Power sequence applied: frontal movement / Secuencia de potencia aplicada: movimiento frontal
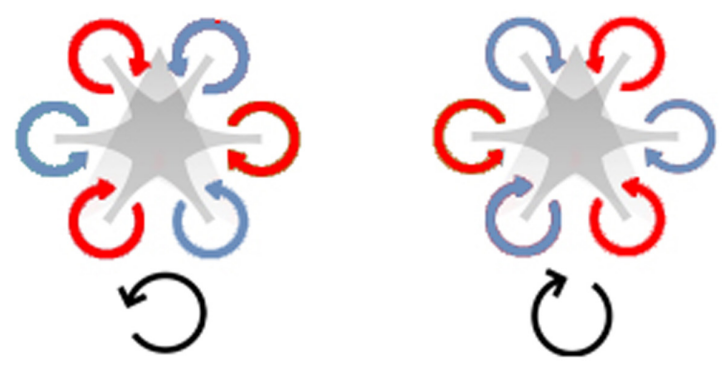

Figure 9. Power sequence applied: rotation movement / Secuencia de potencia aplicada: movimiento de rotación

more power will be applied to the engines highlighted in red in FIGURE 7, whilst the engines highlighted in green will have medium power and the blue ones will receive low power. For the movement towards the left or right, more power will be applied to the highlighted engines in red in Figure 8; if the movement is rotation, most of the power will be applied to the engines in red in Figure 9. If the movement is up or down, also more power will be applied to the engines in red in Figure 10.

\section{B. Artificial vision software}

The implemented system allows the detection of people in the images sent through the UAV transmitter (Maduell \& García, 2010). The image processing is performed with MATLAB, which on its toolset, allows the use of a function known as Vision.CascadeObjectDetector (Gil, 2003). The proposed system in this document — divided into three components as Figure 11 displays - uses this function and can detect object categories where their aspect relation does not vary in a considerable manner.

\section{Integral image}

Consists of a method that reduces the processing time because it does not use RGB information of each pixel, but a simplified representation called "integral image" (Viola \& Jones, 2001). The input image is converted in a gray scale version and for each pixel, the sum of the intensity of the adjacent pixels above and to the left of the original one is assigned. In Figure 12, it is possible to see how each associated value to a pixel is consecuti-
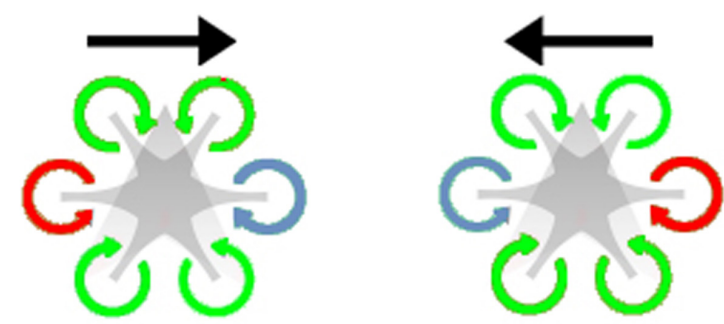

Figure 8. Power sequence applied: lateral movement / Secuencia de potencia aplicada: movimiento lateral
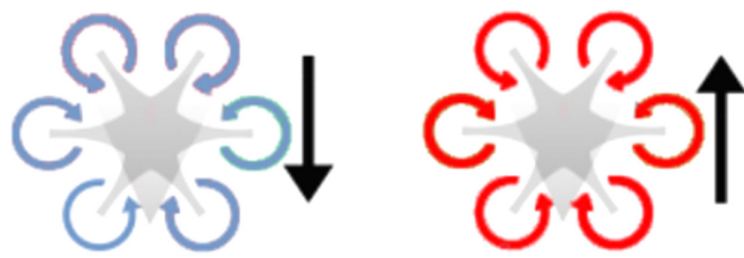

Figure 10. Power sequence applied: movement for elevation and descent / Secuencia de potencia aplicada: movimiento para elevación y descenso

sensores y se calcula el error, junto con los términos integrativo y derivativo, para finalmente, con la constante proporcional, calcular la señal de control que será convertida en la señal PWM de los motores, teniendo en cuenta un anti-windup, el cual fijará los limites inferiores y superiores de los valores que se generen.

Finalmente, para determinar a qué motores los controles PID van a cambiar su potencia (ver Figura 6), es necesario conocer el tipo de movimiento que el operario realizó a través del control remoto. Si el movimiento es hacia adelante o hacia atrás se les aplicará más potencia a los motores indicados en la Figura 7 en rojo, los motores indicados en verde tendrán una potencia media y los motores indicados en azul baja potencia. Para movimiento hacia la derecha o izquierda, se aplicará más potencia a los motores indicados en la Figura 8 en rojo. Si el movimiento es de rotación, se les aplicará más potencia a los motores indicados en la Figura 9 en rojo. Si el movimiento es de ascenso o descenso, se les aplicará más potencia a los motores indicados en la Figura 10 en rojo.

\section{B. Software de visión artificial}

El sistema implementado permite detectar personas en las imágenes enviadas a través del transmisor del UAV (Maduell \& García, 2010). El procesamiento de imágenes se realiza con Matlab que en su kit de herramientas permite utilizar una función conocida como "Vision.CascadeObjectDetector" (Gil, 2003). El sistema propuesto en este documento, que se encuentra dividido en tres componentes (ver Figura 11), hace uso de esta función y puede detectar categorías de objetos cuya relación de aspecto no varía significativamente. 


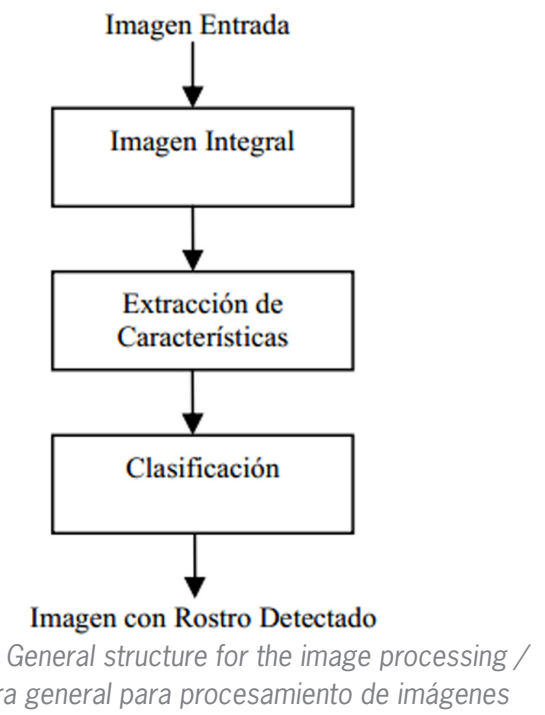

Imagen integral

Consiste en un método que reduce el tiempo de procesamiento debido a que no utiliza la información RGB de cada pixel, sino una representación simplificada denominada imagen integral (Viola \& Jones, 2001). La imagen de entrada se convierte en una versión en escala de grises y se le asigna a cada pixel el valor de la sumatoria de la intensidad de los pixeles vecinos de arriba y a la izquierda de él. En la Figura 12 se observa cómo cada valor asociado a un pixel se suma consecutivamente, con esta técnica se puede obtener la información de intensidad de cualquier parte rectangular de la imagen.

\section{Extracción de características}

Para la detección de rostros se utilizan cuatro tipos de máscaras -tipo 1, horizontal superior; tipo 2, vertical lateral izquierda; tipo 3, vertical centrada; y tipo 4, diagonal inferior izquierda a superior derecha-,que permiten limitar la búsqueda y se mueven cambiando su tamaño a través de toda la imagen, comparando la información de intensidad y la relación de aspecto pixel a pixel de la imagen integral; relacionando la posición relativa, el tamaño y la forma de los ojos, nariz, mejillas y mentón de una cara (Laguna, 2011). Estas máscaras, en forma de vectores, obtienen la información de la imagen integral restando las sumatorias de intensidad de las regiones que la componen. Si es una característica tipo 1 y 2 , se resta la región en blanco de la región en negro; si es tipo 3, se calcula la suma de las áreas de las orillas y se resta el área del centro; si es tipo 4, se restan las sumas de los rectángulos diagonales. La resolución base de estas características es de 24 x 24 pixeles, por lo tanto, se obtienen 180.000 muestras (Viola \& Jones, 2001) en una imagen con relaciones de aspecto variados $(2: 1,1: 2,3: 1,1: 3$ y 2:2). El resultado obtenido por el paso de estas máscaras puede ser - 1 o 1, indicándole a la siguiente etapa del software (extracción de características), si es necesario o no, seguir procesando esa porción de la imagen. La Figura 13, presenta el diagrama de bloques del algoritmo que resume el comportamiento de las primeras dos etapas ya descritas (imagen integral y extracción de características).

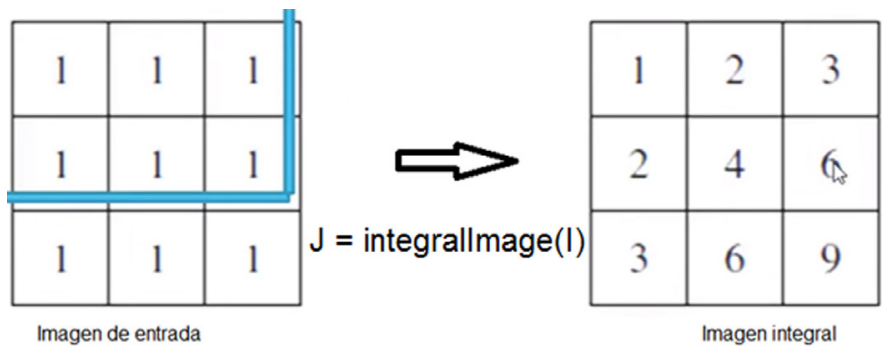

Figure 12. Conversion of the input image to an integral one / Conversión de imagen de entrada a imagen integral

vely added; with this technique, it is possible to obtain the intensity information for any part of the rectangle in the image.

\section{Features extraction}

For the detection of faces, we used four types of masks: type 1 or horizontal superior, type 2 or left vertical, type 3 or centered vertical, and type 4 or left diagonal inferior to right upper. This allows to limit the search and the masks can move changing their size through all the image, comparing the intensity information and the pixel-to-pixel aspect relation of the integral image. Also, this procedure allows the correlation of the relative position, the size and shape of the eyes, nose, cheeks, and chin of a certain face (Laguna, 2011). These masks — vectors shaped - gather the information of the integral image by subtracting the sums of the intensity of the regions forming them. If it is a type 1 or type 2 feature, the performed subtraction is the white region minus the black region; if it is a type 3 , the sum of the areas of the edges is calculated and this result is subtracted to the area of the center. A type 4 feature entails the subtraction of the sums of the diagonal rectangles. The base resolution of these features is $24 \times 24$ pixels; consequently, a total of 180,000 samples are obtained (Viola \& Jones, 2001) in an image with several aspect relations - i.e., 2:1, 1:2, 3:1, 1:3, and $2: 2$ - The results from the bypass of these masks can be either -1 or 1 , indicating to the next stage of the software (features extraction) if it is necessary to continue processing that portion of the image. Figure 13 presents the blocks diagram of the algorithm that summarizes the behavior of the first two stages already described (integral image and features extraction).

\section{Classification}

In the previous stages, the process was to mark sections of the image to analyze. Hence, the detector uses a cascade classifier to decide if that sections contain a face, task performed through a technique called boosting (Morales, 2016). The weak and cascade classifiers of the Vision function were 
configured through the Frontal FaceCART, MinSize, and MaxSize features of the model (ClassificationModel). The stages are designed to reject negative samples as fast as possible. Conversely, the true positives are not common and it is necessary to dedicate larger processing times for their verification. Consequently, a true positive is produced when a positive sample (face) is correctly classified; a false positive is produced when a negative sample (object different to a face) is erroneously classified as a face; and a false negative is produced when a positive sample is erroneously classified as a negative one.

Figure 14 represents the general operation of the classification stage, where the training consists of databases of 4,916 images with a size of $20 \times 20$ pixels, these images show faces of different people belonging to the MATLAB database implemented for the Vision function. The image to be processed is transformed on its integral representation to ease the type 1, 2, 3, and 4 features extraction. Afterwards, if these features deliver a positive result (value 1), the portions potentially detected as faces are delivered to the 38 cascade classifiers - composed of weak classifiers - to compare more than 6,000 unique features present in a face. Finally, when some discard was made and the algorithm has found true positives (faces), these are highlighted with a rectangle.

\section{Tests and results}

The first flights of the drone were very unstable and demand considerable control abilities for the flight operator. With the aim to improve the flight stability and sensitiveness, we proceeded to calibrate the values for the constants $\mathrm{P}$ (proportional), I (integral), and D (Derivative) [PID] of the control. Besides, through the experimentation, we observed which was the reach of the artificial vision system in terms of illumination and maximum vertical and horizontal reconnaissance distance of a person in the scene captured by the camera.

\section{A. MultiWii controller tuning}

In this test, we seek - through the experimentationthe PID values for the MultiWii controller that comply with the following requirements:

- Improve the time response of the drone when a perturbation is presented; if that response is con-

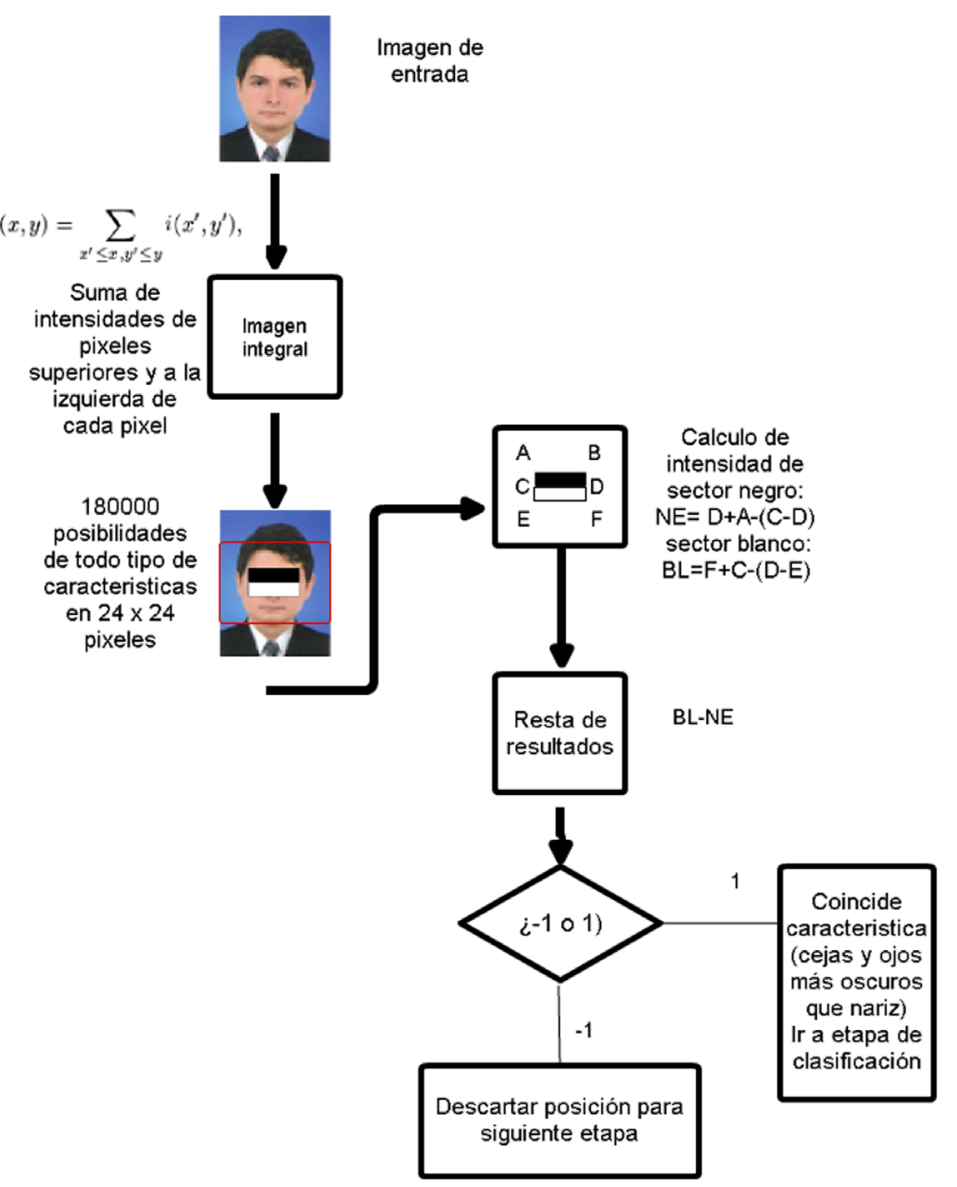

Figure 13. First stages of the face detection algorithm / Primeras etapas del algoritmo de detección de rostros

\section{Clasificación}

En las etapas anteriores se marcaron secciones de la imagen a analizar, el detector utiliza un clasificador de cascada para decidir si esta porción de la imagen contiene una cara, tarea que se realiza a partir de una técnica denominada boosting (Morales, 2016). Los clasificadores débiles y en cascada de la función Vision se configuraron a partir de las propiedades Frontal FaceCART, MinSize y MaxSize del modelo (ClassificationModel). Las etapas están diseñadas para rechazar muestras negativas tan rápido como sea posible. Por el contrario, los verdaderos positivos no son comunes y es necesario dedicar mayor procesamiento para su verificación. Así, un verdadero positivo se produce cuando una muestra positiva (cara) se clasifica correctamente; un falso positivo se produce cuando una muestra negativa (objeto que no sea una cara) se clasifica erróneamente como positivo; y un falso negativo se produce cuando una muestra positiva se clasifica erróneamente como negativa.

La Figura 14 representa el funcionamiento general de la etapa de clasificación, donde el entrenamiento consiste en bases de datos de 4.916 imágenes con tamaño $20 \times 20$ pixeles de caras de diferentes personas pertenecientes a la base de datos de Matlab implementada para la función $\mathrm{Vi}$ sion. La imagen a procesar se transforma en su representa- 


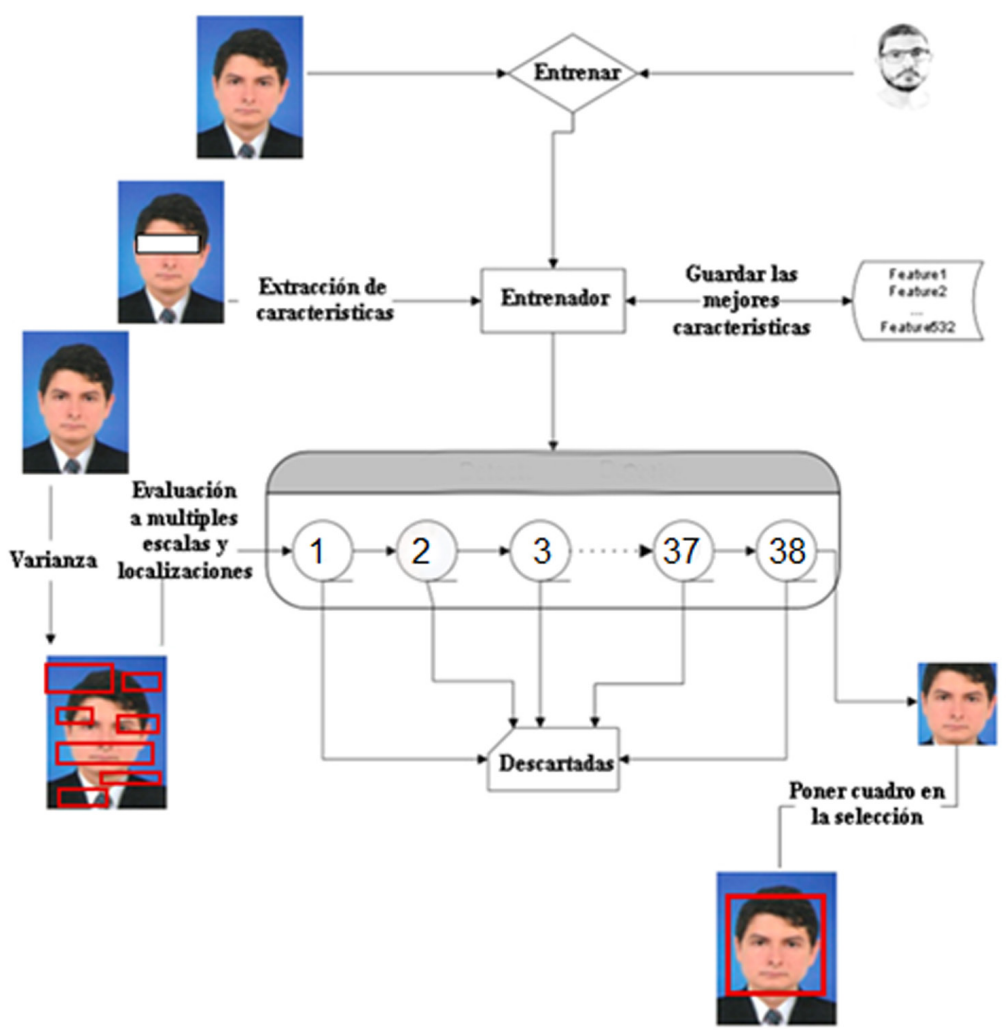

Figure 14. General algorithm for the face detection / Algoritmo general para detección de rostros

ción integral para facilitar la extracción de características tipo 1,2, 3 y 4 , posteriormente, si estas características entregan un resultado positivo (valor 1), se pasan las porciones detectadas posiblemente como caras a través de los 38 clasificadores en cascada compuestos por clasificadores débiles para comparar más de 6.000 características únicas presentes en una cara. Por último, cuando se han descartado y encontrado verdaderos positivos (rostros), éstos se resaltan con un rectángulo.

\section{Pruebas y resultados}

Los primeros vuelos del drón son muy inestables y exigen mucha habilidad de control por parte del piloto. Con el objetivo de mejorar la estabilidad y sensibilidad del vuelo, se procede a calibrar los valores para las constantes P (Proporcional), I (Integral) y D (Derivativa) [PID] del control y a conocer, a través de la experimentación, cuáles son los alcances del sistema de visión artificial en términos de iluminación, distancia vertical y horizontal máxima de reconocimiento de una persona en la escena tomada por la cámara.

\section{A. Sintonización del control multiwii}

En esta prueba se buscan, a través de la experimentación, los valores PID para el controlador MultiWii que cumplan con los siguientes requerimientos:

- mejorar la respuesta en tiempo del drón ante una perturbación, si la respuesta es muy lenta producirá desplazamientos adicionales en el vuelo que el piloto no ha ordenado; siderably slow, it will produce additional movements in the flight the pilot has not ordered.

- Do not produce response angles that tilt considerably the UAV, we recommend a limit of $15^{\circ}$ (depending of the pilot abilities)

- Enhance the stability when the drone is in a totally horizontal position.

At the start of start the tests, the drone had to be tied to a fixed structure with two slings, one in the front part and the other in the opposite to avoid damages on its structure due to the movements relative to the tests. We proceeded to start the engines at approximately $50 \%$ of their total power without producing an elevation of the drone. We checked the stability of the device and the absence of vibration issues.

Then, we hold the drone in the air and accelerate it until it can be "perceived" as lighter. In this point, we tilt the structure to verify the correction angle and the time elapsed to do so. We modified the $\mathrm{P}$ variable through the MultiWii config application, that allows the modification of the PID values and observe the angle, orientation, and power of the drone engines for its posterior analysis. In Figure 15, we modified the $\mathrm{P}$ constant, with the values fixed for $\mathrm{I}=0.03$, and $\mathrm{D}=0$; this entailed a total imbalance in the drone movement. For that reason, we let the values of I and D in 0.03 and 23, respectively (this,

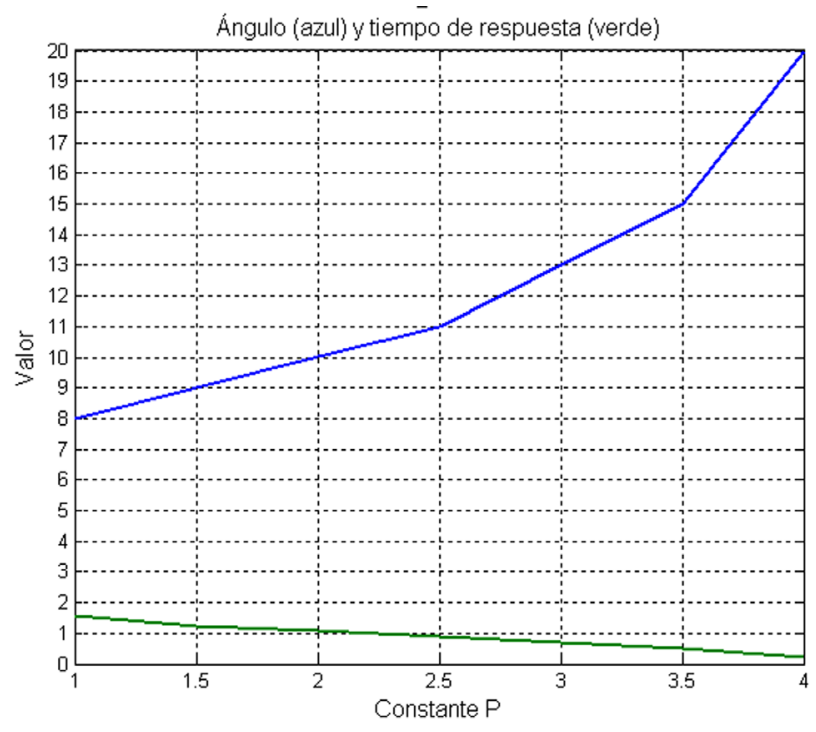

Figure 15. Variation of the $P$ constant / Variación constante $P$ 


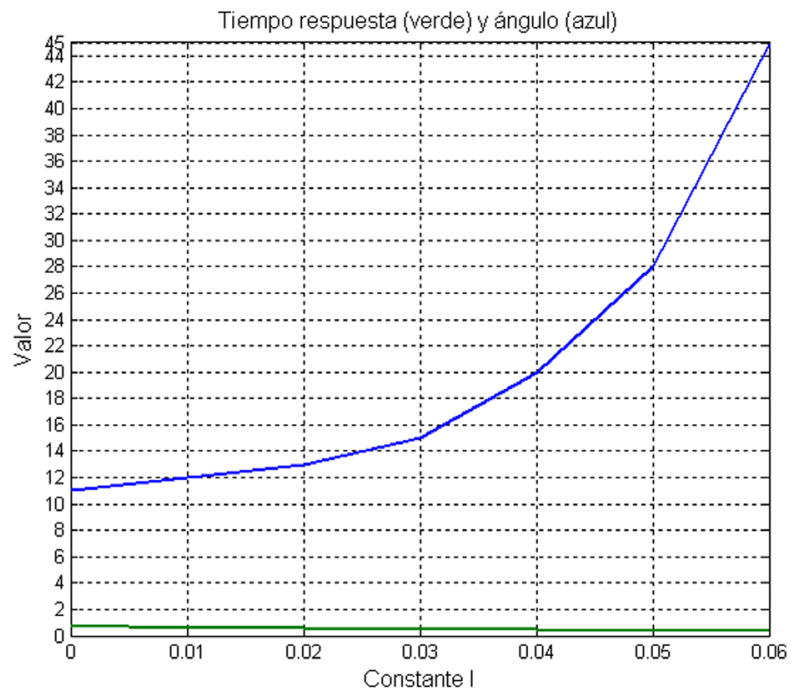

Figura 16. Variación constante I / Variación constante I

because of the fact that those values guarantee stability for this type of tests, as per the experimentation shows).

We deduced, through Figure 15, that with a higher value in the $\mathrm{P}$ constant, a lower response time is obtained, but as a consequence, some dangerous movement correction angles higher than $15^{\circ}$ were obtained. The values between 3 and 4 deliver good results that do not affect the performance of the flight.

In Figure 16, it is possible to see that, the larger the I constant is, the lower is the response time; besides, the correction angle is increased with this affirmation, which can generate instability in the flight and loss of the drone control.

In Figure 17, the reader might see that the derivative constant does not affect the correction angle of the drone; nevertheless, it does affect the response time. The values that presented a better behavior are between 18 and 27.

As a consequence, in this application and to guarantee the compliance of the proposed objectives, the best road to follow is to adopt the following values: $\mathrm{P}=3.5 ; \mathrm{I}=0.03$; and $\mathrm{D}=23$.

\section{B. Tests of performance and reach of the system}

The objective of this test is to know through the experimentation, what is the reach of the artificial vision system in terms of illumination and maximum vertical and horizontal reconnaissance distance of a person in the scene taken by the camera.

The implemented system was tested under two illumination conditions, an acceptable one (more than 3,000 lux) and a regular one (around 100 lux) to know the better and worse results that might be obtained in a real reconnaissance flight. We performed variations in the altitude of the flight

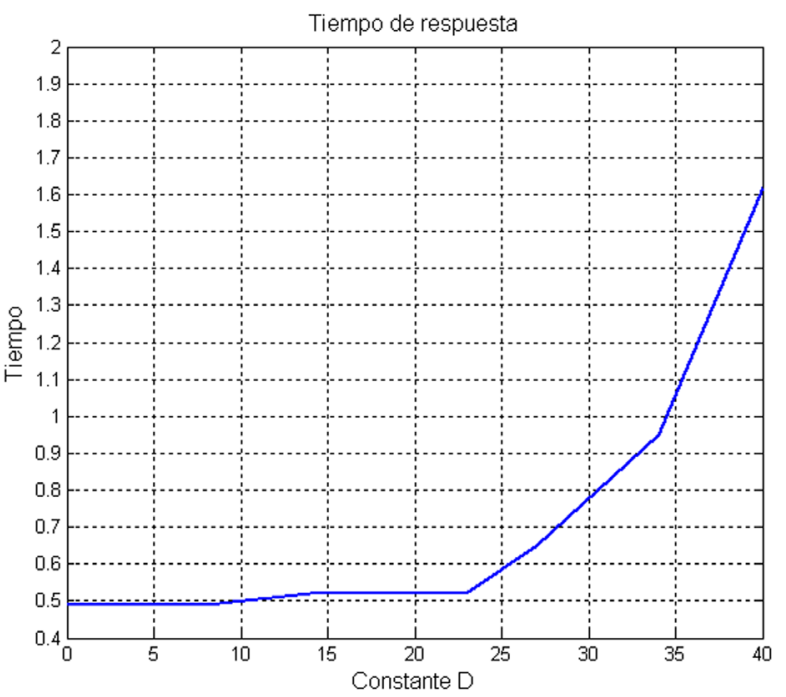

Figura 17. Variación constante D / Variación constante D

- no producir ángulos de respuesta que inclinen mucho al drón, se recomienda un límite de $15^{\circ}$ (dependiendo de la destreza del piloto); y

- mejorar estabilidad cuando se encuentra en posición totalmente horizontal.

Para iniciar la prueba se debe amarrar el drón a una estructura fija con dos eslingas, una en su punta frontal y la otra al lado opuesto para evitar daños en su estructura debido a los movimientos que se producirán en la prueba. Se procede a arrancar los motores a aproximadamente el 50\% de la potencia total sin que el drón se eleve. Se comprueba que esté totalmente estable y que no haya problemas de vibraciones.

Se procede a sostenerlo en el aire y acelerarlo hasta que se pueda percibir un poco más ligero, en este punto se inclina la estructura para verificar el ángulo de corrección y el tiempo que ejerce para corregir la inclinación. Se inicia variando la constante $\mathrm{P}$ a través de la aplicación MultiWii config que permite variar los valores PID y observar el ángulo, la orientación y la potencia de los motores del drón para su posterior análisis. En la Figura 15 se varía la constante P, con los valores I en 0.03 y $\mathrm{D}$ en 0 , consiguiendo un total desbalance en el movimiento del drón, por tal razón, se dejan los valores I y D en 0.03 y 23 respectivamente, pues son valores que garantizan estabilidad para este tipo de pruebas, según la experimentación.

Se deduce, a través de la Figura 15, que con una mayor constante $\mathrm{P}$ se obtiene un menor tiempo de respuesta, pero se obtienen ángulos peligrosos de corrección de movimientos mayores a $15^{\circ}$. Los valores entre 3 y 4 entregan buenos resultados que no afectan el comportamiento de vuelo.

En la Figura 16 se observa que entre más grande sea la constante I, menor es el tiempo de respuesta; también aumenta el ángulo de corrección, lo cual puede generar desequilibrios en vuelo y pérdida del control del drón.

En la Figura 17 se observa que la constante derivativa no afecta el ángulo de corrección del drón, sin embargo, sí afec- 
ta el tiempo de respuesta; los valores que presentan un mejor comportamiento están comprendidos entre 18 y 27.

Por lo tanto, en esta aplicación, para garantizar el cumplimiento de los objetivos propuestos se debe optar por los siguientes valores: $\mathrm{P}=3.5 ; \mathrm{I}=0.03$; y $\mathrm{D}=23$.

\section{B. Prueba de desempeño y alcance del sistema}

El objetivo de esta prueba es conocer, a través de la experimentación, cuáles son los alcances del sistema de visión artificial en términos de: iluminación, distancia vertical y horizontal máxima de reconocimiento de una persona en la escena tomada por la cámara.

El sistema implementado se prueba bajo dos condiciones de iluminación, una aceptable (más de 3.000 Lux) y otra regular (alrededor de los $100 \mathrm{Lux}$ ) para conocer los mejores y peores resultados que se podrían obtener en un vuelo de reconocimiento real, se realizan variaciones sobre la altura de vuelo del drón entre uno y cuatro metros (altura de vuelo máxima recomendada por razones de seguridad en caso de presentarse una colisión) ajustando la distancia horizontal entre el dispositivo y la persona a identificar (uno a cuatro metros, límite máximo de reconocimiento según la experimentación). En la TABLA 1 y en la Figura 18 se presentan algunos resultados obtenidos, donde se considera acierto a la presencia de verdaderos positivos (presencia de rostro real), sin importar que resulten falsos positivos (objeto que no sea una cara se clasifica erróneamente como positivo en la imagen), debido a que ayudará a encontrar a la persona perdida y se podrá descartar fácilmente a los falsos negativos.

En la TABLA 1 se presentan las matrices de confusión de las pruebas realizadas, en ella:

- A, la clase "no caras", es decir, cuando en la imagen a procesar no existe realmente una cara o cuando el software no la detecta;

- B, la clase "caras", es decir, cuando en la imagen a procesar existe realmente una cara o cuando el software detecta una;

- a, cuando se procesa una imagen y no se detecta una cara y realmente en la imagen no existe una cara (Fila: No Cara, Columna: No Cara);

- b, falsos positivos de la clase específica;

- c, falsos negativos (muestra positiva que se clasifica erróneamente como negativa) de la clase específica;

- d, verdaderos positivos (cara real se clasifica correctamente) de la clase específica (Fila: Cara, Columna: Cara);

- TA, total de aciertos, es decir la suma de a $+\mathrm{d}$;

- PA, porcentaje de TA en relación al número total de muestras clasificadas;

- S, sensibilidad o tasa de verdaderos positivos, es decir la proporción de casos positivos que fueron correctamente identificados;

- E, la especificidad o tasa de verdaderos negativos, es decir la proporción de casos negativos que fueron correctamente identificados; between 1 and 4 meters (maximum recommended altitude by safety reasons) by adjusting the horizontal distance between the device and the person to identify (at 4 meters as the maximum reconnaissance limit). In TABLE $\mathbf{1}$ and in Figure 18, we present the obtained results, where a good result is considered as a true positive (presence of a real face), regardless of the presence of false positives (objects that are not a face, but incorrectly classified in the image), since this will help finding the missing person and the discarding of the false positives will be easier.

In TABLE 1, the reader might see the confusion matrices of the performed tests, in them:

- A, the "no caras" (no faces) class, i.e., when in the image to process, there is no face at all, or when the software does not detect it.

- B, the "caras" (faces) class, i.e., when in the image to process, there is a face or when the software detects one.

- a, when an image is processed and a face is not detected; consequently, there is not a face in the image (row: No Cara, column: No Cara)

- $b$, false positives of the specific class

- c, false negatives (positive sample erroneously classified as negative) of the specific class

- $\mathrm{d}$, true positives (real face correctly classified) of the specific class (row: Cara (face), column: Cara (face))

- TA, total of good answers, i.e., the sum of $a+d$

- PA, percentage of the TA relative to the total number of classified samples

- S, sensitiveness or true positives rate, i.e., the proportion of positive cases correctly identified

- $\mathrm{E}$, the specificity or the true negative rate, i.e., the proportion of negative cases correctly identified

- $\overline{\mathrm{P}} \overline{\mathrm{A}}$, the mean or average of PA

- $\overline{\mathrm{S}}$, the mean or average of $\mathrm{S}$;

- $\overline{\mathrm{E}}$, the mean or average of $\mathrm{E}$

In the results of Table 1 , the sensitiveness is considered as the capacity of the test to detect a face, i.e., the ability the software has to generate positive cases. On the other hand, in FIgURE 18, we present the special conditions where the system will not be able to produce true positives under no distance (horizontal or vertical) and illumination condition. This latter is due to the employed algorithm and its configuration. Due to this, the task to identify people is in charge of the operator.

The system has a general classification performance near $65 \%$ for the cases where a good illumination is present, and 
Table 1. General performance of the detection system / Desempeño general del sistema de detección

\begin{tabular}{llll}
\hline \multirow{2}{*}{ Lighted environment / Entorno con luz } & \multicolumn{2}{c}{ Prediction / predicción } \\
\cline { 2 - 4 } & & No face / sin cara & Face/c \\
\hline Real value / Valor real & No face / sin cara & 3 & 6 \\
\cline { 2 - 4 } & Face/cara & 1 & 10 \\
\hline & & & \\
\hline Classifier/ clasificador & \multicolumn{2}{c}{ Data (\%) } \\
Vision function/ función visión & Light/ luz & No light/ no luz \\
\hline PA & 65 & 73 \\
$\mathrm{~S}$ & 91 & 89 \\
$\mathrm{E}$ & 33 & 50 \\
$\overline{\mathrm{PA}}$ & & 69 \\
$\overline{\mathrm{S}}$ & & 90 \\
$\overline{\mathrm{E}}$ & & 42 \\
\hline
\end{tabular}

$73 \%$ in the low illumination scenario. Nevertheless, it is valid to clarify:

- the system is single target (it only recognizes one true positive at the time);

- the reconnaissance is made for a person in frontal profile and not in a lateral one, since the training does not have a database of photos in a lateral position; and

- the obstruction of the face does not allow its detection.

Regarding the maximum reach distances, we could identify that at an altitude between 1 and 2 meters, it is possible to obtain a scenario with a maximum horizontal detection distance of 4 meters with an illumination higher than 3,457 lux. In similar illumination conditions but at 3 meters of altitude, the horizontal detection distance is also 3 meters.

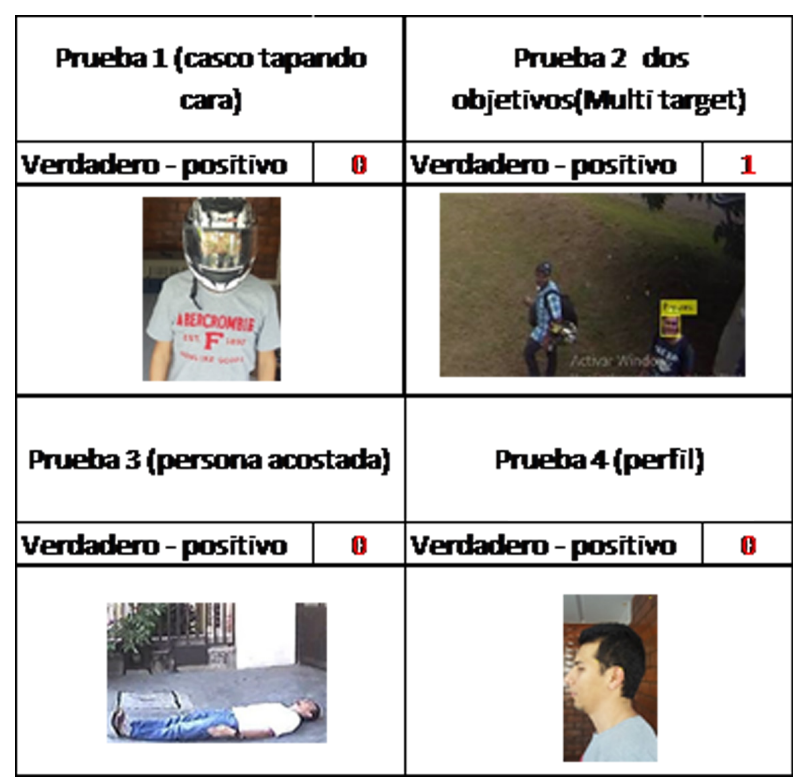

Figure 18. General performance of the system / Desempeño general del sistema
Lighted environment / Entorno con luz Prediction / predicción

No face/sin cara Face/cara

\begin{tabular}{llll} 
Real value / & No face / sin cara & 3 & 3 \\
\cline { 2 - 4 } Valor real & Face/cara & 1 & 8 \\
\hline
\end{tabular}

- $\overline{\mathrm{PA}}$, la media o promedio de PA;

- $\overline{\mathrm{s}}$, la media o promedio de $\mathrm{S} ; \mathrm{y}$

- $\overline{\mathrm{E}}$, la media o promedio de E.

En los resultados de la TABLA 1, se considera a la sensibilidad como la capacidad de la prueba para detectar la cara de una persona, es decir, la capacidad del software para generar casos positivos. Por otro lado, en la Figura 18 se presentan las condiciones especiales en las cuales el sistema no podrá producir verdaderos positivos bajo ninguna condición de distancia (horizontal o vertical) o iluminación, debido al algoritmo usado y a la forma en este se configuró. Debido a esto, la tarea de identificación de personas queda a cargo del operario.

El sistema tiene un desempeño general de clasificación cercano al 65\% para los casos de buena iluminación (más de 3.000 Lux) y $73 \%$ para los casos de baja iluminación (alrededor de 100 Lux). No obstante, es válido aclarar que:

- el sistema es single target (solo reconoce un verdadero positivo a la vez);

- se reconocen personas de forma frontal y no de forma lateral, debido a que el entrenamiento no posee base de datos de perfiles de personas; y

- la obstrucción del rostro impide su detección.

Con respecto a las distancias máximas de detección, se pudo identificar que una altura de entre uno y dos metros permite una distancia horizontal máxima para detección de cuatro metros con una iluminación mayor a 3457 Lux. En similares condiciones de iluminación, a tres metros de altura, la distancia horizontal de detección es también de tres metros.

C. Prueba para definir distancia máxima de vuelo y autonomía de vuelo para el sistema

El objetivo de esta prueba es verificar la máxima cantidad de tiempo que el drón puede volar al máximo de su potencia, esto quiere decir que en condiciones de vuelo donde se requiera menos potencia, podría aumentar su autonomía. En esta prueba se analiza la autonomía de vuelo del drón, registrando el voltaje de la batería con los motores a máxima potencia, a través del programa UT60A V4.01 de Windows, tomando un total de 1.829 muestras en 569 segundos.

La autonomía de vuelo del UAV en relación al comportamiento del voltaje de la batería operando a $38^{\circ} \mathrm{C}$, es de aproximadamente nueve minutos y veintisiete segundos, tiempo en el cual la batería disminuyó su voltaje hasta 9.5 $\mathrm{V}$ (ver Figura 19). 


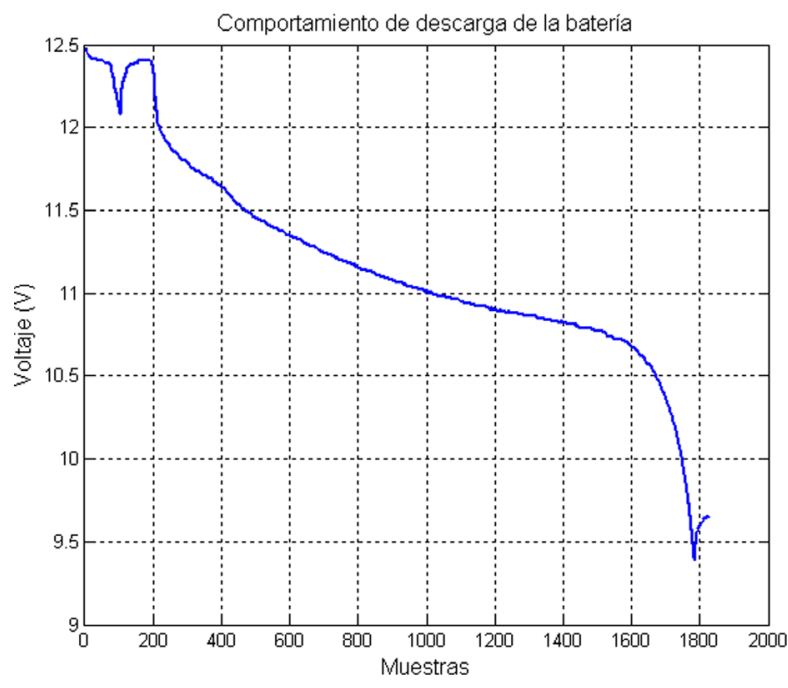

Figure 19. Discharge behavior of the test battery operating at maximum power/Comportamiento de descarga de la batería de prueba de vuelo real a máxima potencia

Para conocer la distancia máxima real que soportan los dispositivos de transmisión y recepción del sistema se procede a registrar las coordenadas de un sitio de prueba inicial a través de la aplicación móvil de Android Google Maps, luego se mueve el drón a una altura de 1.75 metros y se aleja del receptor hasta que se pierda la señal de video, registrando las coordenadas de dónde se produjo este evento. La distancia máxima de funcionamiento que soporta el receptor y transmisor de video es de 349 metros (ver Figura 20), ésta es la distancia máxima para el funcionamiento del sistema de detección de personas, sin embargo el UAV tiene un alcance de operación de hasta dos kilómetros ( $\sin$ la función de reconocimiento de personas).

\section{Conclusiones}

A través de la comparación de las dos tipologías (estructura de ala fija y de rotores) usadas para la construcción de UAV en la actualidad, la elección de una estructura con rotores facilita la tarea de identificar la presencia de personas en una escena en tierra, debido a que esta configuración permite mantener el vehículo en posiciones más estables durante el vuelo, facilitando la obtención de imágenes con mejor composición, mientras que el otro tipo de estructura exige un constante movimiento del vehículo, lo cual requeriría un sistema de visión artificial más robusto para cumplir con la tarea de detección de rostros.

En la actualidad hay gran variedad de métodos relacionados con el reconocimiento facial derivados de técnicas holísticas y de modelos 3D, la mayoría cumple satisfactoriamente con el objetivo propuesto, sin embargo, cada aplicación particular tiene características especiales de diseño, por lo cual no toda técnica tendrá la garantía de funcionar correctamente. Debido a esto, se deben conocer los requerimientos del sistema a desarrollar para adaptar el funcionamiento de los algoritmos de visión artificial a

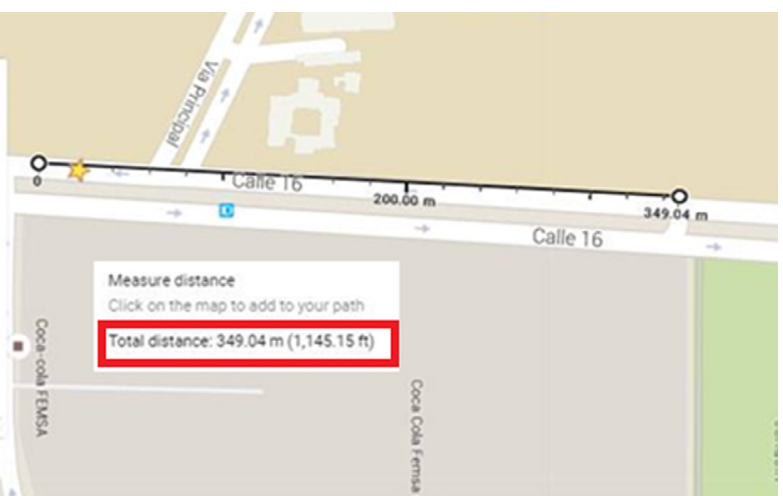

Figure 20. Maximum flight distance for the operation of the people detection system/ Distancia máxima de vuelo para el funcionamiento del sistema de detección de personas

\section{Test to define the maximum flight distance and flight autonomy for the system}

The objective of this test is to verify the maximum amount of time the drone can flight using its maximum power; that is, in flight conditions where less power is required, the system autonomy might be higher. In this test, we analyzed the flight autonomy of the UAV by storing the voltage of the battery with the engines at full power through the UT60A software for Windows. We took a total of 1,829 samples in 569 seconds.

The flight autonomy of the UAV relative to the behavior of the battery operating at $38^{\circ}$ Celsius is approximately 9 minutes and 27 seconds, time where the battery reduced the voltage up to $9.5 \mathrm{~V}$ (see Figure 19).

With the intention of knowing the maximum real distance supported by the transmission and reception devices of the system, we proceeded to store the coordinates of an initial test place through the Google Maps application. After that, the drone flew to an altitude of 1.75 meters and got away of the receiver until the video signal was lost; we stored the coordinates where this happened. The maximum operation distance the video receiver/transmitter supported was 349 meters (see Figure 20). This latter value is the maximum distance for the operation of the people detection system; however, the UAV has a reach to be operated up to 2 kilometers (without the mentioned function).

\section{Conclusions}

Through the comparison of the two typologies (fixed wing structure and with rotors) employed for the construction of UAVs nowadays, the choice of a structure with rotors facilitates the task to identify persons in the ground. This due to the fact that this configuration allows to maintain the vehicle in more stable positions during the flight, easing the gathering of images with better composition values; whilst 
the other structure type demands a constant movement of the vehicle, which would require a more robust artificial vision system to comply with the face detection task.

There is a wide variety of methods related with the facial recognition derived from holistic techniques and 3D models, most of them successfully comply with the proposed objective. Nevertheless, each particular application has specific design features; hence, not all the techniques will have the guarantee to correctly operate. Due to this, the requirements of the system to develop should be well known to adapt the operation of the artificial vision algorithms to the required specific necessities. In this project, we could set and configure the method that best fits our particular necessities through the revision, implementation, and tests carried out plus the definition of the involved variables in the reconnaissance tasks (variable light conditions and non-static and far UAV and objectives). The employed method was the Viola \& Jones algorithm, which uses an appropriate use of resources such as execution time and computational cost, reducing the unnecessary processing of images not corresponding to a face.

According to TABLE 1, the obtained results in the tests entailed that the drone should be piloted with a horizontal distance of between 2 and 4 meters between it and the person to identify and with altitudes between 2.5 and 3.5 meters (this also considering the safety recommendations in flight to avoid accidents) in order the vision system performs a correct classification of true positives.

We were able to design a platform with good features: 2,000 meters of maximum distance relative to the pilot depending on the site where the drone is operated, wireless video transmission up to a maximum of 349 meters, and ease in the scalability of the flight control. This allows to solve the problem planted at the beginning of this document

The employed modular design for the implementation of the UAV is recommendable for technological integration applications, since it allows that the functional requirements of the system to be supported in different modules. This helps to reduce the complexity of the system and eases the maintenance, modification, and upgrading tasks.

Along with the last paragraph, some future perspectives of the project involve the inclusion of geolocation instruments, as well as devices for the gathering of images in the infrared (IR) spectrum and some fusion of information (visible/IR), besides of the implementation of cooperative communication and autonomous strategies. ST las necesidades específicas que este demande. En este proyecto, a través de la revisión, implementación y pruebas realizadas de algunos métodos de visión artificial, además de la definición de las variables específicas involucradas en la tarea de reconocimiento - condiciones de luz cambiantes, objetivos y drón no estáticos y lejanos entre sí-, se logra establecer y configurar el método que mejor se adapta a éstas necesidades (algoritmo de Viola \& Jones), método que hace un uso apropiado de recursos como tiempo de ejecución y costo computacional, disminuyendo el procesamiento innecesario en secciones de una imagen que no corresponden a una cara.

De acuerdo con la TABLA $\mathbf{1}$, los resultados obtenidos en dicha prueba y teniendo en cuenta recomendaciones de seguridad en vuelo para evitar accidentes, se debe volar el drón con una distancia horizontal entre la persona a identificar y el dispositivo de entre dos y cuatro metros, a alturas comprendidas entre 2.5 y 3.5 metros, para que el sistema de visión realice una clasificación correcta de verdaderos positivos.

Se logró diseñar una plataforma de buenas características (2000 metros de distancia máxima con respecto al piloto, dependiendo del sitio en que se vuele el drón, transmisión inalámbrica de video máximo a 349 metros y fácil escalabilidad del control de vuelo), que permite darle solución al problema planteado en este documento.

El diseño modular utilizado para la implementación del UAV es recomendable para aplicaciones de integración tecnológica, permite que los requisitos funcionales del sistema se soporten en diferentes módulos, lo cual ayuda a reducir la complejidad del sistema y facilita las tareas de mantenimiento, modificación y actualización.

Con base en lo anterior, algunas perspectivas futuras del proyecto involucran la inclusión de instrumentos de geolocalización, así como dispositivos para adquisición de imágenes en espectro infrarrojo IR, fusión de información (visible/IR), implementación de comunicación y estrategias de operación autónoma cooperativas. SKT 


\section{References / Referencias}

Issod, C. (2015). Getting started with hobby quadcopters and drones. Seattle, WA: Createspace.

Futaba. (2017). The Futaba 2.4GHz Story. Retrieved from: http://www.futabarc.com/technology/fasst.html

Gil, M. (2003). Introducción rápida a Matlab y Simulink para ciencia e ingeniería. Madrid, España: Díaz de Santos.

Guerrero, R. \& Coronel, F. (2013). Sistema de navegación de un cuadricóptero guiado por el movimiento de las manos para operaciones de búsqueda y rescate [tesis]. Universidad Politécnica Salesiana: Cuenca, Ecuador.

Laguna, C. (2011). Evaluación experimental de detectores de caras y características faciales [tesis]. Universidad Pública de Navarra: España.

Maduell, I. \& García, E. (2010). Visión artificial. Barcelona, España: Fundación para la Universitad Oberta de Catalunya.

Morales, A. (2016). Uso de características no lineales para identificar llantos de recién nacidos con un conjunto clasificador [tesis]. Universidad de las Américas: Puebla, México.

Newcome, L. R. (2004). Unmanned aviation: A brief history of unmanned aerial vehicles. Reston, VA: American Institute of Aeronautics and Astronautics.

Taborda, D. \& Velásquez, A. (2013). Sistema de adquisición de datos de una unidad de navegación inercial y ROS como herramienta de visualización. Scientia Et Technica, 18(3), 524-529. doi:10.22517/23447214.1707

Torres, A., Gómez, A., \& Jimenez, A. (2015). Development of a multispectral system for precision agriculture applications using embedded devices. Sistemas \& Telemática, 13(33), 27-44. doi:10.18046/syt.v13i33.2079

US Department of Defense [USDoD]. (2017). Department of Defense dictionary of military and associate terms. Washington, DC: DoD.

Viola, P., \& Jones, M. (2001). Rapid object detection using a boosted cascade of simple features. In Computer Vision and Pattern Recognition, 2001. CVPR 2001. Proceedings of the 2001 IEEE Computer Society Conference on (Vol. 1). IEEE. doi:10.1109/CVPR.2001.990517 


\section{CURRICULUM VITAE}

Andrés Felipe Espinal Rojas Technologist in Electronic from Universidad del Valle (Palmira, Colombia) and Electronic Engineer from Institución Universitaria Antonio José Camacho (Cali, Colombia) / Tecnólogo en Electrónica de la Universidad del Valle (Palmira, Colombia) e Ingeniero Electrónico de la Institución Universitaria Antonio José Camacho (Cali, Colombia).

Andrés Arango Espinal Technologist in Electronic from Universidad del Valle (Palmira, Colombia) and Electronic Engineer from Institución Universitaria Antonio José Camacho (Cali, Colombia) / Tecnólogo en Electrónica de la Universidad del Valle (Palmira, Colombia) e Ingeniero Electrónico de la Institución Universitaria Antonio José Camacho (Cali, Colombia).

Luis Angel Ramos Lengua Technologist in Electronic from Universidad del Valle (Cali, Colombia) and Electronic Engineer from Institución Universitaria Antonio José Camacho (Cali, Colombia) / Tecnólogo en Electrónica de la Universidad del Valle (Cali, Colombia) e Ingeniero Electrónico de la Institución Universitaria Antonio José Camacho (Cali, Colombia).

Jorge Humberto Erazo Aux Electronic Engineer (2014), Master in Engineering with emphasis in Electronics (2010) and student of the Doctorate in Engineering with emphasis in Electrics and Electronics of the Universidad del Valle. Full time and auxiliary professor affiliated to the engineering faculty of the Institución Universitaria Antonio José Camacho (Cali-Colombia). Thermography professional level I and II of the Infrared Training Center - ITC (2007 and 2011). His areas of interest are: thermography, artificial vision, digital signal processing, and pattern recognition / Ingeniero Electrónico (2004), Magister en Ingeniería con énfasis en Electrónica (2010) y estudiante de Doctorado en Ingeniería con énfasis en Eléctrica y Electrónica de la Universidad del Valle (Cali - Colombia). Profesor auxiliar de tiempo completo adscrito a la Facultad de Ingeniería de la Institución Universitaria Antonio José Camacho (Cali-Colombia). Termógrafo nivel I y II del Infrared Training Center - ITC (2007 y 2011). Sus áreas de interés son: termografía, visión artificial, procesamiento digital de señales y reconocimiento de patrones. 